\title{
Dual cobalt(II)/silver catalysis: Synthesis of aryliminated pyrrolo[2,3-b]indoles via multicomponent bicyclization cascades
}

\author{
Wen-Juan Hao, ${ }^{\mathrm{a}}$ Ya-Nan Wu, ${ }^{\mathrm{a}}$ Qian Gao, ${ }^{\mathrm{a}}$ Shu-Liang Wang, ${ }^{\mathrm{a}}$ Shu-Jiang Tu, ${ }^{, \mathrm{a}}$ and Bo Jiang ${ }^{*}$,a \\ ${ }^{\text {a }}$ School of Chemistry and Chemical Engineering, and Jiangsu Key Laboratory of Green Synthetic Chemistry for Functional Materials, Jiangsu Normal \\ University, Xuzhou, 221116, P. R. China, E-mail: jiangchem@jsnu.edu.cn;
}

\section{ARTICLE INFO}

\section{Article history:}

Received

Received in revised form

Accepted

Available online

\section{Keywords:}

Dual bimetallic catalysis

Bicyclization

Pyrrolo[2,3-b]indoles

\section{ABSTRACT}

Dual cobalt(II)/silver catalysis enables multicomponent bicyclization cascades of 2ethynylanilines, tert-butyl isocyanide and arylamines, resulting in subsequent multiple bondforming events to rapidly build up aryliminated pyrrolo[2,3-b]indoles. The reaction pathway involves bimetal-catalyzed isocyanide insertion/1,3-dipolar cycloaddition/ imination substitution sequence.
Dual catalysis has become a very useful synthetic strategy for the assemble of unusual functional molecules which are difficult to obtain through traditional methods. During these processes, both the nucleophile and the electrophile are respectively activated by two different catalysts, facilitating their sequential coupling to prepare the desired compounds and remarkably improving reaction efficiency and selectivity. As a result, considerable effort has been devoted to synergistic catalysis in organic community. ${ }^{1}$ However, the exploration of dual catalysis is challenging due to the fact that different catalysts may interfere with each other in one pot, thereby weakening their catalytic activities. To overcome this limitation, during the past few years the chemists have developed several compatible co-catalyst systems including a combination of transition-metal and organocatalysis, ${ }^{2}$ transition-metal and photoredox catalysis, ${ }^{3}$ and prevalent bimetallic catalysis. ${ }^{4}$ Despite these high synthetic potential, the success of synergistic catalysis remains immature and there is a strong demand to develop new synergistic catalysis, especially those with perfectly compatible catalytic system.

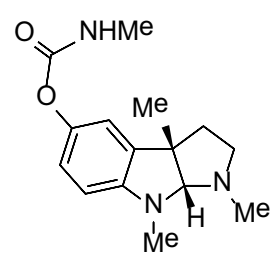

pysostigmine

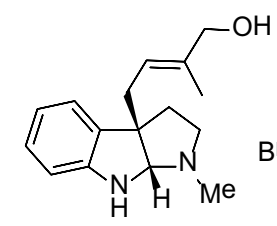

pseudophrvnaminol

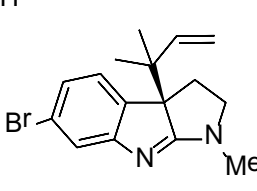

flustramine $\mathrm{C}$
Figure 1. Representative pyrrolo[2,3- $b$ ]indole alkaloids Pyrrolo[2,3- $b$ ]indoles are an important class of aza-heterocycles ${ }^{5}$ that are widely distributed in numerous natural products such as pysostigmine, ${ }^{6}$ pseudophrvnaminol ${ }^{7}$ and flustramine $\mathrm{C}^{8}$ (Figure 1). Accordingly, many methods for the synthesis of this structural skeleton have been developed, which mainly involved the following three categories: i) tandem cyclization of tryptophan derivatives; ${ }^{9-13}$ ii) copper-catalyzed coupling of iodotryptophans $^{14}$ iii) aza-Pauson-Khand cyclocarbonylations. ${ }^{15}$ Despite these limited advances, the development of a direct and general catalytic protocol toward pyrrolo[2,3-b]indoles, especially through synergistic catalysis, has been an attractive target.

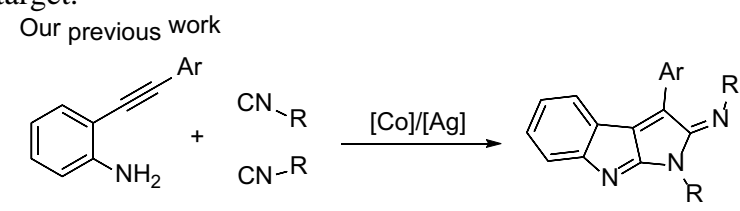

Zhang's work

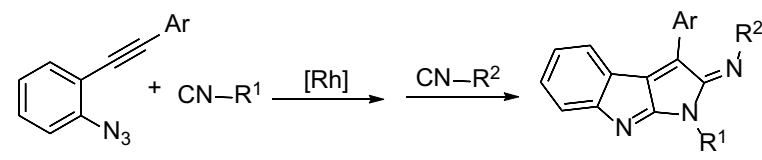

This work

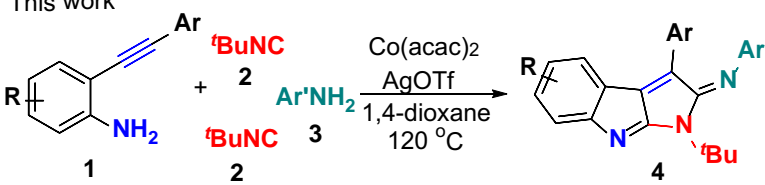

Scheme 1. Double insertion reaction of isocyanides

On the other hand, isocyanides have been served as powerful building blocks, which are extensively used in multicomponent reactions, ${ }^{16}$ insertion reactions, ${ }^{17}$ and oligo-/polymerization 
processes. ${ }^{18}$ Very recently, we have reported an interesting $\mathrm{Co} / \mathrm{Ag}$ synergistic catalysis of isocyanides and 2-ethynylanilines, enabling isocyanide insertion/1,3-dipolar cycloaddition to access pyrrolo[2,3-b]indoles (Scheme 1a). ${ }^{19}$ Later on, Zhang and coworkers presented $\mathrm{Rh}(\mathrm{I})$-catalyzed cascade reaction of 2azidoalkynylbenzenes with two different isocyanides by two steps, affording pyrrolo[2,3- $b$ ] indoles (Scheme $1 b$ ). ${ }^{20}$ During this project, we found that when tert-butyl isocyanide $\mathbf{2}$ was subjected with reaction of 2-ethynylanilines and aromatic amines, this dual cobalt(II)/silver catalysis could occur, delivering aryliminated pyrrolo[2,3- $b$ ]indoles via multicomponent bicyclization cascades (Scheme 1c). Herein, we would like to report this interesting observation.

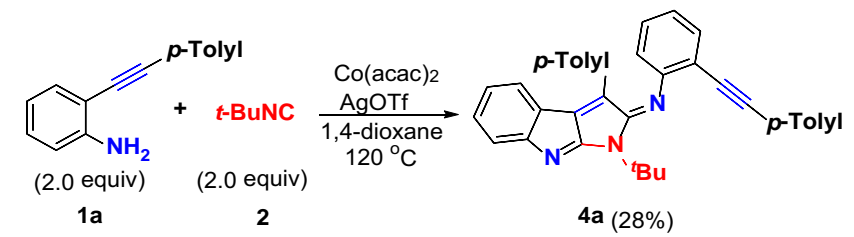

Scheme 2. Cascade reaction between 2-ethynylanilines and tertbutyl isocyanide 22

In our previous report, the cobalt(II)/silver-co-catalyzed bicyclization cascades of 2-ethynylanilines with cyclohexyl isonitrile (adamantanyl (Ada) and 4-bromophenyl) in a 1:2 molar ratio in 1,4-dioxane at $120{ }^{\circ} \mathrm{C}$ gave access to a range of functionalized pyrrolo[2,3-b]indoles. ${ }^{19}$ To expand the synthetic utility of this methodology, tert-butyl isocyanide (2) was selected and subjected to the reaction of 2-(p-tolylethynyl)aniline (1a) under the aforementioned reaction conditions, the reaction proceeded to generate the unexpected pyrrolo[2,3-b]indoles $4 \mathbf{4}$, albeit with $28 \%$ yield; this may be caused by the strong steric hindrance of 2-ethynylanilines. During this process, two molecule of arylethynylanilines and isocyanides were merged into the final pyrrolo[2,3- $b$ ]indoles (Scheme 2). In view of these useful results, we made our efforts to evaluate the feasibility of the synthesis of pyrrolo[2,3-b]indoles by replacing a molecule of arylethynylanilines with small steric aryl amines $\mathbf{3}$. As per our expectation, the four-component reaction of $\mathbf{1}$ with $\mathbf{2}$ and aryl amines $\mathbf{3}$ under the above-described conditions provided ploysubstituted 2-aryliminated pyrrolo[2,3- $b$ ]indoles $\mathbf{4}$ in good yields (Scheme 3). In the beginning, upon repeating the reaction with 2( $p$-tolylethynyl)aniline (1a) and tert-butyl isocyanide (2), we were pleased to find that aryl amines $\mathbf{3}$ bearing electron-donating, -neutral, and -withdrawing substituents at the para-positions of the phenyl ring participated well in this synergistic bimetallic catalysis, delivering the collection of highly substituted pyrrolo[2,3- $b$ ]indoles $\mathbf{4 b - f}$ in 53\%-67\% yields. Next, the scope of arylalkynes 1 was next explored, employing tert-butyl isocyanide $\mathbf{2}$ and $p$-toluidine $\mathbf{3 a}$ as model substrates. Various 2ethynylanilines possessing arylvinyl moiety attached by electrondonating $(\mathrm{Me}$ and $\mathrm{MeO})$, neutral $(\mathrm{H})$, or withdrawing $(\mathrm{F}$ and $\mathrm{Cl})$ groups were compatible, and the target pyrrolo[2,3- $b$ ]indoles $\mathbf{4 g}$ $\mathbf{4 j}$ were obtained in synthetically useful yields. The sterically more demanding 1-naphthyl (1-Np) (1f) counterpart was an adaptable component, enabling dual $\mathrm{Co} / \mathrm{Ag}$ catalysis to access the desired product $\mathbf{4 k}$ in a $72 \%$ yield under the standard conditions. Similarly, 2-ethynylanilines with various functional groups (Me, CN, F, and $\mathrm{Cl}$ ) located at the 4-position of the internal arene ring would be accommodated, confirming the reaction efficiency, as $\mathbf{4 m - 4 q}$ were afforded in $50 \%-62 \%$ yields.
Note that this is the special procedure for the assemble of these new imino-functionalized pyrrolo[2,3- $b$ ]indoles through $\mathrm{Co} / \mathrm{Ag}$ catalyzed double isocyanide insertion/ 1,3-dipolar cycloaddition/ imination substitution. Besides, the NMR and HR-MS spectroscopic analysis for in den o[1,2- $d]$ py $r$ id a zin e 4, the Xray diffraction for product $\mathbf{4 a}$ has been performed as shown in Figure 1.

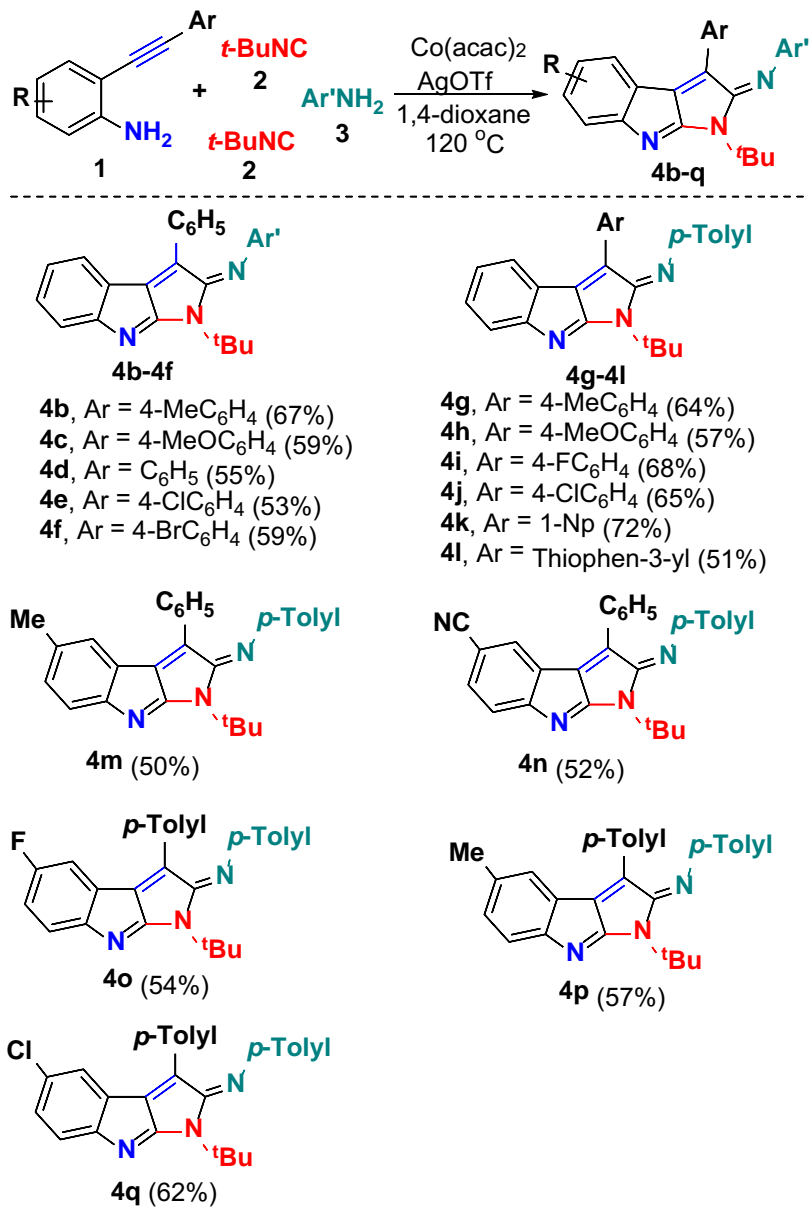

Scheme 3. Scope of cobalt/silver-co-catalyzed multicomponent bicyclization reaction. ${ }^{22}$ Yields of isolated products after column chromatography on silica gel are given. $1(0.5 \mathrm{mmol})$ and tert-butyl isocyanide $(1.2 \mathrm{mmol})$, aromatic amines $(0.6 \mathrm{mmol})$, catalyst $(10 \mathrm{~mol} \%)$, dry 1,4-dioxane $(4.0 \mathrm{~mL})$, under $\mathrm{N}_{2}$ atmosphere, $24 \mathrm{~h}$; after completion, all the reaction mixtures were stirred at room temperature under air conditions for 5 $\mathrm{h}$

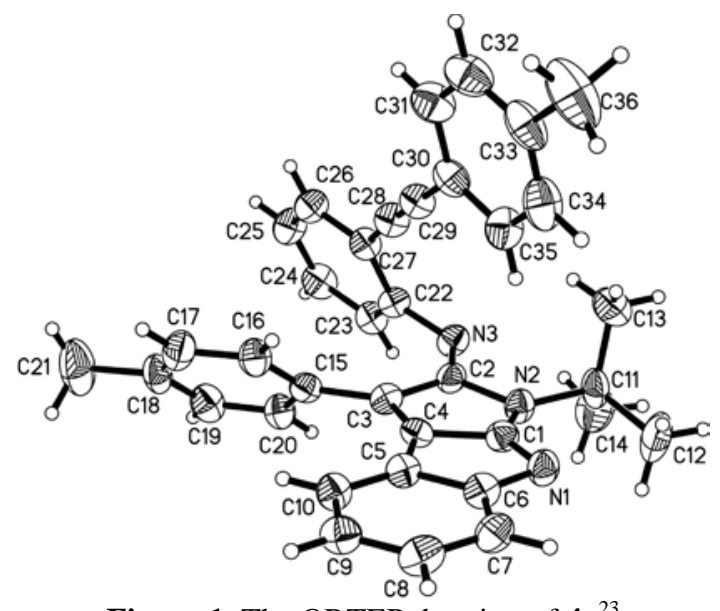

Figure 1. The ORTEP drawing of $\mathbf{4} \mathbf{a}^{23}$

Although the detailed mechanism of this reaction has not been fully confirmed at this point, on the basis of our previous report, ${ }^{20}$ a possible reaction pathway for forming pyrrolo[2,3- $b$ ]indoles 4 
is proposed in Scheme 4. The insertion of the ligated isonitrile into $\mathrm{N}-\mathrm{H}$ bond of arylethynylanilines 1 affords enyne-imine specie $\mathbf{B},{ }^{21}$ which is converted into 1,3-dipoles $\mathbf{C}$. In the presence of silver triflate, intramolecular 1,3-diplar cycloadditions leads to pyrrolo[2,3-b]indole intermediate $\mathbf{D}$, followed by imination substitution with arylamines $\mathbf{3}$ (D to $\mathbf{F}$ ) to access aryliminated pyrrolo[2,3-b]indoles $\mathbf{4}$ through dehydrogenation.

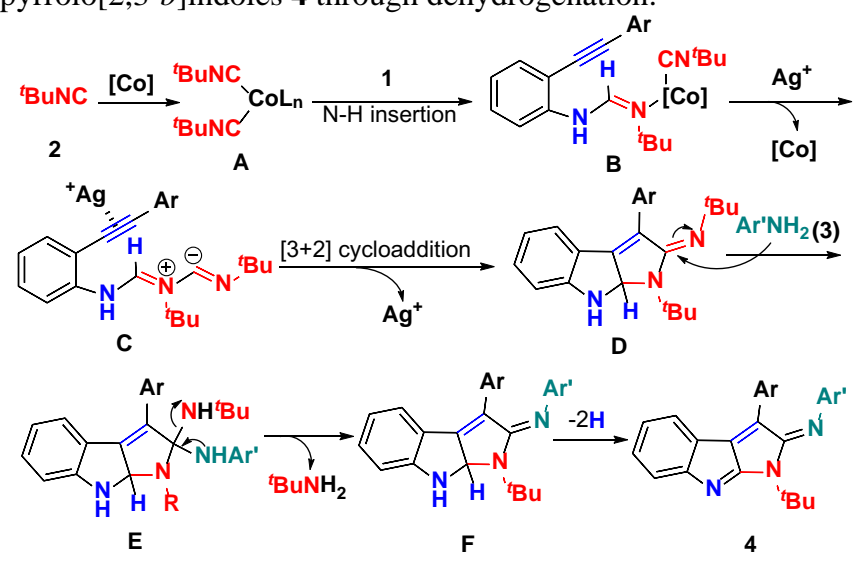

Scheme 4. The proposed mechanism

In summary, a facile cobalt(II)/silver co-catalyzed bicyclization of arylethynylanilines with isonitriles and arylamines has been established, by which a range of aryliminated pyrrolo[2,3- $b]$ indoles with high stereoselectivity were prepared in a convergent manner. The reaction also features dual $\mathrm{Co} / \mathrm{Ag}$ catalysis and flexible structural modification. A detailed application of resulting pyrrolo[2,3$b$ ]indoles is currently underway in our laboratory.

\section{Acknowledgments}

We are grateful for financial support from the NSFC (Nos. 21232004 and 21472071), PAPD of Jiangsu Higher Education Institutions, the Outstanding Youth Fund of JSNU (YQ2015003), NSF of Jiangsu Province (BK20151163, BK20160212), NSF of JSNU (14XLR005), the Qing Lan Project and NSF of Jiangsu Education Committee (15KJB150006)

\section{References and notes}

(1) For selected reviews on dual catalysis: (a) Allen, A. E.; MacMillan, D W. C. Chem. Sci. 2012, 3, 633. (b) Shao, Z.; Zhang, H. Chem. Soc. Rev. 2009, 38, 2745. (c) Hanna, L. E.; Jarvo, E. R. Angew. Chem., Int. Ed. 2015, 54, 15618. (d) Brimioulle, R.; Lenhart, D.; Maturi, M. M.; Bach, T. Angew. Chem., Int. Ed. 2015, 54, 3872.

(2) For selected examples on synergistic transition-metal/organo-catalysis: (a) Wei, Y.; Yoshikai, N. J. Am. Chem. Soc. 2013, 135, 3756. (b) Skucas, E.; MacMillan, D. W. C. J. Am. Chem. Soc. 2012, 134, 9090. (c) DiRocco, D. A.; Rovis, T. J. Am. Chem. Soc. 2012, 134, 8094. (d) Zhou, H.; Zhang, L.; Xu, C.; Luo. S. Angew. Chem., Int. Ed. 2015, 54, 12645 .

(3) For selected recent examples on synergistic transition-metal/photoredox catalysis: (a) Sahoo, B.; Hopkinson, M. N.; Glorius, F. J. Am. Chem. Soc. 2013, 135, 5505. (b) Tellis, J. C.; Kelly, C. B.; Primer, D. N.; Jouffroy, M.; Patel, N. R.; Molander, G. A. Acc. Chem. Res. 2016, 49, 1429. (c) Leveque, C.; Chenneberg, L.; Corce, V.; Goddard, J. P.; Ollivier, C.; Fensterbank, L. Org. Chem. Front. 2016, 3, 462. (d) Gui, Y. Y.; Sun, L.; Lu, Z. P.; Yu, D. G. Org. Chem. Front. 2016, 3, 522.

(4) For selected examples on bimetallic catalysis, see: $\mathrm{Fe}-\mathrm{Cu}$ catalysis: (a) Shirakawa, E.; Ikeda, D.; Masui, S.; Yoshida, M.; Hayashi, T. J. Am. Chem. Soc. 2012, 134, 272. Pd-Cu catalysis: (b) Yao, B.; Jaccoud, C.; Wang, Q.; Zhu, J. Chem.-Eur. J. 2012, 18, 586. (c) Nahra, F.; Mace, Y.; Boreux, A.; Billard, F.; Riant, O. Chem.-Eur. J. 2014, 20, 10970. (d) Vercruysse, S.; Cornelissen, L.; Nahra, F.; Collard, L.; Riant, O. Chem.Eur. J. 2014, 20, 1834. Rh-Cu catalysis: (e) Wang, N.-N.; Huang, L.-R.;
Hao, W.-J.; Zhang, T.-S.; Li, G.; Tu, S.-J.; Jiang, B. Org. Lett. 2016, 18, 1298.

(5) For examples, see: (a) Classics in Total Synthesis, 1st ed. (Eds.: Nicolaou, K. C.; Sorensen E. J.), Wiley-VCH, 1996; (b) Classics in Total Synthesis II, (Eds.: Nicolaou, K. C.; Snyder S. A.), Wiley-VCH: Weinheim, 2003.

(6) (a) Pandey, G.; Khamrai, J.; Mishra, A. Org. Lett. 2015, 17, 952; (b) Liu, J.; Ng, T.; Rui, Z.; Ad, O.; Zhang, W. Angew. Chem., Int. Ed. 2014, 53, 136; (c) Chiou, W.-H.; Kao, C.-L.; Tsai, J.-C.; Chang, Y.-M. Chem. Commun. 2013, 49, 8232.

(7) (a) Ruiz-Sanchis, P.; Savina, S. A.; Albericio, F.; Alvarez, M. Chem.Eur. J. 2011, 17, 1388; (b) Kawasaki, T.; Ogawa, A.; Takashima, Y.; Sakamoto, M. Tetrahedron Lett. 2003, 44, 1591; (c) Spande, T. F.; Edwards, M. W.; Pannell, L. K.; Daly, J. W.; Erspamer, V.; Melchiorri, P. J. Org. Chem. 1988, 53, 1222 .

(8) (a) Kawasaki, T.; Shinada, M.; Ohzono, M.; Ogawa, A.; Terashima, R.; Sakamoto, M. J. Org. Chem. 2008, 73, 5959; (b) Lindel, T.; Braeuchle, L.; Golz, G.; Boehrer, P. Org. Lett. 2007, 9, 283; (c) Kawasaki, T.; Terashima, R.; Sakaguchi, K.-e.; Sekiguchi, H.; Sakamoto, M. Tetrahedron Lett. 1996, 37, 7525.

(9) Metal-catalyzed cyclization of tryptophans sees: (a) Tu, D.; Ma, L.; Tong, X.; Deng, X.; Xia, C. Org. Lett. 2012, 14, 4830; (b) Song, H.; Yang, J.; Chen, W.; Qin, Y. Org. Lett. 2006, 8, 6011; (c) Zhang, D.; Song, H.; Qin, Y. Acc. Chem. Res. 2011, 44, 447.

(10) Organocatalytic cyclization of tryptophans sees: (a) Lozano, O.; Blessley, G.; Martinez del Campo, T.; Thompson, A. L.; Giuffredi, G. T.; Bettati, M.; Walker, M.; Borman, R.; Gouverneur, V. Angew. Chem., Int. Ed. 2011, 50, 8105; (b) Austin, J. F.; Kim, S.-G.; Sinz, C. J.; Xiao, W.-J.; MacMillan, D. W. C. Proc. Natl. Acad. Sci. U.S.A. 2004, 101, 5482;

(11) Bromination-cyclization of tryptophans sees: (a) Kim, J.; Movassaghi, M. J. Am. Chem. Soc. 2010, 132, 14376; (b) Ohno, M.; Spande, T. F.; Witkop, B. J. Am. Chem. Soc. 1968, 90, 6521 .

(12) Selenocyclization of tryptophans sees: (a) Oelke, A. J.; France, D. J.; Hofmann, T.; Wuitschik, G.; Ley, S. V. Angew. Chem., Int. Ed. 2010, 49, 6139; (b) Depew, K. M.; Marsden, S. P.; Zatorska, D.; Zatorski, A.; Bornmann, W. G.; Danishefsky, S. J. J. Am. Chem. Soc. 1999, 121, 11953; (c) Crich, D.; Huang, X. J. Org. Chem. 1999, 64, 7218.

(13) Oxidative cycloaromatization of tryptophans sees: Ohno, M.; Spande, T. F.; Witkop, B. J. Am. Chem. Soc. 1970, 92, 343

(14) Coste, A.; Toumi, M.; Wright, K.; Razafimahaleo,V.; Couty, F.; Marrot, J.; Evano, G. Org. Lett. 2008, 10, 3841.

(15) (a) Mukai, C.; Yoshida, T.; Sorimachi, M.; Odani, A. Org. Lett. 2006, 8, 83; (b) Aburano, D.; Yoshida, T.; Miyakoshi, N.; Mukai, C. J. Org. Chem. 2007, 72, 6878

(16) (a) Multicomponent Reactions (Eds.: Zhu, J.; Bienayme H.), WileyVCH, Weinheim, 2005. (b) Gao, Q.; Hao, W.-J.; Liu, F.; Tu, S.-J.; Wang, S.-L.; Li, G.; Jiang, B. Chem. Commun. 2016, 52, 900. (c) Ma, G.-H.; Jiang, B.; Tu, X.-J.; Ning, Y.; Tu, S.-J.; Li, G. Org. Lett. 2014, 16,4504 .

(17) For selected reviews, see: (a) Lygin, A. V.; de Meijere, A. Angew. Chem. Int. Ed. 2010, 49, 9094; (b) Qiu, G.; Ding, Q.; Wu, J. Chem. Soc. Rev. 2013, 42, 5257. For selected examples, see: (c) Pan, Y.-Y.; Wu, Y.-N.; Chen, Z.-Z.; Hao, W.-J.; Li, G.; Tu, S.-J.; Jiang, B. J. Org. Chem. 2015, 80, 5764; (d) Jiang, H.; Gao, H.; Liu, B.; Wu, W. Chem. Commun. 2014, 50, 15348; (e) Jiang, H.; Yin, M.; Li, Y.; Liu, B.; Zhao, J.; Wu, W. Chem. Commun. 2014, 50, 2037.

(18) Suginome, M.; Ito, Y. Adv. Polym. Sci. 2004, 171, 77.

(19) Gao, Q.; Zhou, P.; Liu, F.; Hao, W.-J.; Yao, C.; Jiang, B.; Tu, S.-J. Chem. Commun. 2015, 51, 9519

(20) Zhang, Z.; Xiao, F.; Huang, B.; Hu, J.; Fu, B.; Zhang, Z. Org. Lett. 2016, 18,908 .

(21) (a) Meier, M.; van Eldik, R. Chem.-Eur. J. 1997, 3, 39; (b) Harrowfield, J. M.; Sargeson, A. M. J. Am. Chem. Soc. 1979, 101, 1514. (c) Zhu, T.H.; Xu, X.-P.; Cao, J.-J.; Wei, T.-Q.; Wang, S.-Y.; Ji, S.-J. Adv. Synth. Catal. 2014, 356, 509 .

(22) Typical procedure for the synthesis of 4a: Under a nitrogen atmosphere, 2-(p-tolylethynyl)aniline (1a, $207 \mathrm{mg}, 1.0 \mathrm{mmol}), \mathrm{Co}(\mathrm{acac})_{2}(25.7 \mathrm{mg}$, $0.1 \mathrm{mmol}, 10 \mathrm{~mol} \%)$ and AgOTf $(25.7 \mathrm{mg}, 0.1 \mathrm{mmol}, 10 \mathrm{~mol} \%)$ were introduced into a $25-\mathrm{mL}$ Schlenk reaction flask, tert-butyl isocyanide $(2,99.6 \mathrm{mg}, 1.2 \mathrm{mmol}, 1.2$ equiv) and dry 1,4-dioxane $(4.0 \mathrm{~mL})$ were then successively added into this reaction mixture. The reaction system was stirred at $120{ }^{\circ} \mathrm{C}$ for $12 \mathrm{~h}$. After the completion of the reaction (monitored by TLC), the reaction mixture was continuously stirred at room temperature under air conditions for $5 \mathrm{~h}$ until the reaction solution turned red. Next, the solvent was removed under vacuum. The residue was separated by column chromatography on silica gel (eluent, petroleum ether/ethyl acetate) to afford the pure red solid 4a. Red solid, mp 194-195 ${ }^{\circ} \mathrm{C} .{ }^{1} \mathrm{H}$ NMR $\left(400 \mathrm{MHz}, \mathrm{CDCl}_{3}\right) \delta=7.33(\mathrm{~d}, J=8.0 \mathrm{~Hz}$, 
2H, Ar-H), 7.15-7.07 (m, 6H, Ar-H), $7.00(\mathrm{~d}, J=8.0 \mathrm{~Hz}, 2 \mathrm{H}, \mathrm{Ar}-\mathrm{H})$, 6.85-6.80 (m, 3H, Ar-H), 6.71-6.65 (m, 2H, Ar-H), $6.52(\mathrm{~d}, J=8.0 \mathrm{~Hz}$, $1 \mathrm{H}, \mathrm{Ar}-\mathrm{H}), 2.33\left(\mathrm{~s}, 3 \mathrm{H}, \mathrm{CH}_{3}\right), 2.20\left(\mathrm{~s}, 3 \mathrm{H}, \mathrm{CH}_{3}\right), 1.87\left(\mathrm{~s}, 9 \mathrm{H}, \mathrm{CH}_{3}\right) .{ }^{13} \mathrm{C}$ NMR $\left(100 \mathrm{MHz}, \mathrm{CDCl}_{3}\right) \delta=172.6,157.3,148.8,141.4,138.2,137.9$, 132.1, 131.6, 131.2, 130.1, 129.9, 129.1, 128.3, 128.2, 128.1, 127.9, 123.6, 122.7, 122.5, 120.8, 120.4, 119.0, 114.5, 110.1, 93.1, 87.3, 58.8, 29.8, 21.5, 21.2. HRMS (APCI): $\mathrm{m} / \mathrm{z}$ calcd for: $\mathrm{C}_{36} \mathrm{H}_{33} \mathrm{~N}_{3}, 508.2753$ $[\mathrm{M}+\mathrm{H}]^{+}$; found: 508.2776. Typical procedure for the synthesis of products $4 \mathbf{b}$ : Under a nitrogen atmosphere, 2-(phenylethynyl)aniline (1b, $96.5 \mathrm{mg}, 0.5 \mathrm{mmol}$ ), p-toluidine (3a, $64.2 \mathrm{mg}, 0.6 \mathrm{mmol}, 1.2$ equiv), $\mathrm{Co}(\mathrm{acac})_{2}(12.8 \mathrm{mg}, 0.05 \mathrm{mmol}, 10 \mathrm{~mol} \%)$ and AgOTf $(12.8$ $\mathrm{mg}, 0.05 \mathrm{mmol}, 10 \mathrm{~mol} \%$ ) were introduced into a $25-\mathrm{mL}$ Schlenk reaction flask, tert-butyl isocyanide $(2,99.6 \mathrm{mg}, 1.2 \mathrm{mmol}, 2.4$ equiv) and 1,4-dioxane $(4.0 \mathrm{~mL})$ were then successively added into this reaction mixture. The reaction system was stirred at $120{ }^{\circ} \mathrm{C}$ for $24 \mathrm{~h}$. After the completion of the reaction (monitored by TLC), the reaction mixture was continuously stirred at room temperature under air conditions for $5 \mathrm{~h}$ until the reaction solution turned red. Next, the solvent was removed under vacuum. The residue was separated by column chromatography on silica gel (eluent, petroleum ether/ethyl acetate) to afford the pure red solid $\mathbf{4 b}$. Red solid, mp $149-150{ }^{\circ} \mathrm{C} .{ }^{1} \mathrm{H}$ NMR (400 MHz, $\left.\mathrm{CDCl}_{3}\right) \delta=7.19-6.95(\mathrm{~m}, 8 \mathrm{H}, \mathrm{Ar}-\mathrm{H}), 6.71(\mathrm{~s}, 1 \mathrm{H}, \mathrm{Ar}-$ $\mathrm{H}), 6.68-6.43(\mathrm{~m}, 4 \mathrm{H}, \mathrm{Ar}-\mathrm{H}), 2.10\left(\mathrm{~s}, 3 \mathrm{H}, \mathrm{CH}_{3}\right), 1.84\left(\mathrm{~s}, 9 \mathrm{H}, \mathrm{CH}_{3}\right) .{ }^{13} \mathrm{C}$ NMR $\left(100 \mathrm{MHz}, \mathrm{CDCl}_{3}\right) \delta=172.4,163.2,156.3,144.1,142.5,132.8$, $132.3,131.9,128.4,128.2,128.2,127.7,127.3,123.6,123.4,122.5$, 121.2, 118.9, 58.8, 29.8, 20.6. HRMS (APCI): $\mathrm{m} / \mathrm{z}$ calcd for: $\mathrm{C}_{27} \mathrm{H}_{25} \mathrm{~N}_{3}$, $392.2127[\mathrm{M}+\mathrm{H}]^{+}$; found: 392.2154 .

(23) Crystal data for 4a (CCDC 1499409): $\mathrm{C}_{36} \mathrm{H}_{31} \mathrm{~N}_{3}, M r=505.64$, Monoclinic, space group $P 2(1) / c$ with $a=9.1198(9), b=17.4080(16), c$ $=19.2261(18) \AA, \alpha=90.00^{\circ}, \beta=111.966(3)^{\circ}, \gamma=90.00^{\circ}, V=2830.7(5$ $\AA^{3}, Z=4, D c=1.186 \mathrm{~g} / \mathrm{cm}^{3}, \mu(\mathrm{MoK} \alpha)=0.534 \mathrm{~mm}^{-1}, F(000)=1072$, the final $R=0.0732$ and $w R=0.0836$. 


\section{Graphical Abstract}

To create your abstract, type over the instructions in the template box below. Fonts or abstract dimensions should not be changed or altered.

Dual cobalt(II)/silver catalysis: Synthesis of aryliminated pyrrolo[2,3-b]indoles via multicomponent bicyclization cascades

Wen-Juan Hao, Ya-Nan Wu, Qian Gao, Shu-Liang Wang, Shu-Jiang Tu, and Bo Jiang
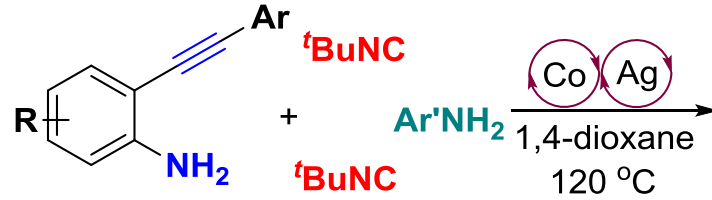<smiles>[R]#CC1=C([Al])C(=N[Al])n2c1nc1ccccc12</smiles> 